\title{
Evaluasi Penggunaan Metode Prechtl untuk Menilai Kualitas Gerakan Spontan Bayi Muda Sehat: Pengalaman RSU Dr. Soetomo Surabaya
}

\author{
Ahmad Suryawan, Komang Ayu Witarini, Risa Etika, Fatimah Indarso, Irwanto, \\ Moersintowati B. Narendra, Sylviati M. Damanik \\ Departemen Ilmu Kesehatan Anak, Fakultas Kedokteran Universitas Airlangga, RSU Dr Soetomo Surabaya
}

\begin{abstract}
Latar belakang. Penilaian kualitas gerakan spontan pada bayi dengan metode "General movements (GMs)" dari Prechtl mempunyai validitas tinggi untuk memprediksi risiko gangguan perkembangan anak. Metode GMs masih relatif baru di Indonesia, sehingga dibutuhkan evaluasi aspek praktikalnya untuk dapat diaplikasikan secara optimal.

Tujuan. Mengetahui kondisi paling optimal untuk menilai kualitas gerakan spontan bayi muda sehat menggunakan metode GMs dari Prechtl.

Metode. Dilakukan rekaman video secara berurutan pada bayi yang memenuhi kriteria inklusi lahir sehat, cukup bulan, tanpa risiko, dan mendapat persetujuan tertulis dari orangtua, lahir di RSU Dr SoetomoSurabaya pada kurun waktu Desember 2006-Januari 2007. Teknik perekaman dilakukan sesuai standarisasi Prechtl, dengan berbagai variasi waktu dan kondisi. Analisis video rekaman dilakukan secara persepsi Gestalt oleh salah satu peneliti, yang sebelumnya telah mendapat kursus dan sertifikat metode GMs. Parameter aspek praktikal untuk evaluasi digolongkan: optimal dan tidak optimal.

Hasil. Tidak didapatkan penolakan dari orang tua untuk seluruh 56 bayi yang memenuhi kriteria inklusi. Tiga $(5,4 \%)$ video yang tidak dapat dianalisis karena faktor kesalahan teknis perekaman. Kualitas GMs lebih optimal untuk dianalisis apabila perekaman dilakukan pada waktu siang hari dibandingkan waktu pagi $(p=0,026)$ atau malam $(p=0,045)$, dan dilakukan 30 menit sebelum waktu minum, dibandingkan 30 menit sesudahnya $(p=0,032)$. Tingkat kesulitan analisis tidak berbeda bermakna apabila perekaman dilakukan di tempat yang khusus dibandingkan dilakukan di boks $(p=0,156)$ atau inkubator $(p=0,466)$.

Kesimpulan. Metode Prechtl dapat diterapkan dengan praktis dan optimal apabila pengambilan video dilakukan pada waktu siang hari dan 30 menit sebelum waktu minum. Tempat pengambilan rekaman tidak mempengaruhi segi kepraktisannya (Sari Pediatri 2008;9(6):363-9).
\end{abstract}

Kata kunci: gangguan perkembangan, gerakan spontan, metode Prechtl

\footnotetext{
Alamat Korespondensi:

Dr. Ahmad Suryawan, Sp.A, Divisi Tumbuh Kembang Anak dan Remaja Bagian Ilmu Kesehatan Anak RSU Dr Soetomo, Jl Prof Dr Moestopo 68 Surabaya. Telp. 0813 32064107, Fax.: 031-5501748, E-mail: drwawan@lycos.com
} 
Ahmad Suryawan dkk: Metode Prechtl untuk Menilai Kualitas Gerakan Spontan Bayi Muda Sehat

M endeteksi gangguan perkembangan anak pada usia dini merupakan satu hal yang sangat sulit. Hal ini tercermin dari nilai validitas prediktif yang bervariasi dari berbagai teknik pemeriksaan yang telah dikembangkan. Mulai dari metode pemeriksaan klinik sederhana sampai dengan metode pemeriksaan yang membutuhkan peralatan canggih untuk memeriksa fungsi integritas susunan saraf bayi dan mengidentifikasi kemungkinan risiko terjadinya gangguan perkembangan pada masa anak. ${ }^{1,2}$ Saat ini berkembang suatu teknik baru untuk memeriksa fungsi integritas otak bayi melalui penilaian gerakan spontan pada bayi muda, dengan suatu metode yang dikenal dengan metode "General Movements (GMs)" yang diperkenalkan pertama kali oleh Heinz Prechtl sejak awal tahun $1980 .{ }^{3}$ Selama lebih dari dua dasawarsa, metode Prechtl telah menjadi metode pemeriksaan yang telah dibakukan melalui pelatihan dan pemberian sertifikasi bagi peneliti atau klinisi terutama di berbagai Negara Eropa. ${ }^{1-3}$ Metode Prechtl dikenal dapat dilakukan secara praktis, tidak invasif dan relatif murah, dengan nilai validitas prediktif yang terbukti sangat tinggi dan akurat untuk dapat meramalkan seorang bayi berada pada risiko tinggi untuk mengalami gangguan perkembangan. ${ }^{3-5}$

Meskipun dikenal sangat aplikatif, metode Prechtl belum dapat diterapkan secara luas di luar Eropa dan Amerika, karena sampai saat ini masih sedikit klinisi yang berkesempatan mendapat pelatihan dan bersertifikat. Oleh sebab itu dipandang sangat perlu untuk melakukan validasi metode Prechtl pada populasi yang berbeda. ${ }^{6}$ Demikian pula di Indonesia, metode Prechtl belum dikenal dan digunakan secara luas terbukti sejauh sepengetahuan kami belum pernah ada studi yang sudah dipublikasikan di Indonesia yang terkait dengan metode Prechtl. Atas dasar itu kami di Bagian IKA FK UNAIR rumah sakit Dr. Soetomo Surabaya mencoba untuk menerapkan penggunaan metode ini. Oleh karena merupakan pengalaman kami yang pertama, maka tujuan penelitian untuk mengetahui kondisi yang paling optimal untuk dapat menerapkan metode Prechtl secara praktis sebatas kemampuan terbaik yang kami miliki. Hasil penelitian diharapkan dapat dipakai sebagai metode baku awal penerapan Metode Prechtl pada populasi bayi di Indonesia yang tentunya mempunyai karakterisktik yang berbeda dengan populasi bayi di negara Eropa atau benua lainnya. Oleh karena belum dibakukan istilah "General
Movements (GMs)" dalam istilah medis di Indonesia, maka dalam makalah ini kami menggunakan istilah aslinya sebagai GMs yang banyak dipakai dalam berbagai jurnal kedokteran internasional.

\section{Metode}

\section{Subjek}

Penelitian dilakukan secara prospektif di NICU dan Ruang Neonatologi RS Dr Soetomo Surabaya, pada kurun waktu Desember 2006 sampai Januari 2007. Subjek diambil secara berurutan dari bayi baru lahir yang memenuhi kriteria inklusi yaitu lahir tunggal, cukup bulan (berdasarkan usia gestasi), terlahir sehat tanpa risiko (tidak asfiksia, tidak ada kelainan neurologi secara klinis, dan tidak ada risiko infeksi) dan terbebas dari penggunaan peralatan medis yang dapat menghalangi gerakan spontan bayi. Subjek akan dieksklusi apabila secara klinis dijumpai kelainan kongenital mayor. Pada semua bayi dibuat sebuah rekaman video berdasarkan izin (informed consent) tertulis dari orangtua.

\section{Teknik penilaian kualitas gerakan spontan bayi}

Kualitas gerakan spontan bayi dinilai menggunakan penilaian kualitas GMs menurut standarisasi metode Prechtl, ${ }^{7}$ melalui sebuah rekaman video. Rekaman video menggunakan sebuah alat rekam video portabel digital merk Sony DCR-HC30E ${ }^{\circledR}$ yang terpasang diatas tripod merk Sony VCT-D480RM ${ }^{\circledR}$. Kamera video diletakkan pada posisi mid-sagital atau lateral diatas tubuh bayi, yang diatur sedemikian rupa sehingga tubuh bayi dapat nampak seluruhnya dalam layar monitor pada jarak yang paling dekat.

Setiap bayi direkam saat kurun waktu usia minggu pertama, dengan posisi supine (terlentang) di atas tempat khusus berupa mattrass yang diletakkan di atas lantai atau di atas bed (box) bayi, atau bisa juga di dalam inkubator, tergantung pada kondisi bayi saat itu. Pengambilan rekaman dilakukan pada saat pagi hari (jam 08.00-10.00) atau siang hari (jam 13.0015.00) atau malam hari (jam 20.00-22.00) di antara dua (30 menit sebelum atau 30 menit sesudah) jadwal minum. Durasi waktu rekaman untuk setiap bayi antara 15-30 menit, berdasarkan pengalaman sebuah penelitian sebelumnya. ${ }^{6}$ 
Analisis hasil rekaman video dilakukan oleh salah satu tim peneliti (AS) yang sebelumnya telah mendapatkan pelatihan dan sertifikasi metode GMs tingkat dasar dari Institute Developmental Neurology, Universiteit Medisch Centrum Groningen (UMCG), Belanda. Analisis dilakukan tanpa mengetahui latar belakang kondisi klinis pra dan pasca-natal setiap bayi yang direkam. Teknik analisis GMs menggunakan penilaian kualitatif secara persepsi Gestalt dengan cara mengevaluasi aspek kompleksitas dan variasi dari setiap gerakan bayi, yang kemudian digolongkan sesuai standar klasifikasi menurut Hadders-Algra M, $2004^{1}$ (Tabel 1).

Analisis dilakukan hanya untuk video yang berhasil merekam bayi yang sebagian besar waktunya menunjukkan perilaku sesuai stadium Prechtl 2 atau Prechtl $4^{8}$ (Tabel 2). Untuk setiap video dilakukan evaluasi aspek pelaksanaan praktis berdasarkan tingkat kesulitan pembacaan, dengan memakai dua parameter yaitu video yang optimal dan video yang tidak optimal.

Kriteria video optimal

1. Bayi sebagian besar waktunya berada pada Prechtl stadium 4

2. Durasi gerakan secara total lebih dari $>5$ menit

3. Tidak banyak diselingi fase menangis

Tabel 1. Klasifikasi kualitas GMs menurut Hadders-Algra M, $2004^{1}$

\begin{tabular}{lccc} 
Klasifikasi & Kompleksitas & Variasi & Fluensi \\
\hline Normal-optimal GMs & ++ & ++ & + \\
Normal-suboptimal GMs & ++ & ++ & - \\
Abnormal-ringan GMs & + & + & - \\
Abnormal-pasti GMs & - & - & - \\
\hline
\end{tabular}

Tabel 2. Penggolongan stadium perilaku bayi menurut Prechtl $^{8}$

\begin{tabular}{|c|c|}
\hline Stadium & Deskripsi perilaku \\
\hline 1 & $\begin{array}{l}\text { Mata tertutup, respirasi regular, sedikit sekali } \\
\text { gerakan }\end{array}$ \\
\hline 2 & $\begin{array}{l}\text { Mata tertutup, respirasi ireguler, sejumlah } \\
\text { gerakan kecil-kecil dan kadang-kadang } \\
\text { memproduksi general movements (GMs) }\end{array}$ \\
\hline 3 & Mata terbuka, tidak nampak gerakan \\
\hline 4 & $\begin{array}{l}\text { Mata terbuka, memproduksi gerakan spontan } \\
\text { secara kontinyu }\end{array}$ \\
\hline 5 & Dominasi keadaan menangis \\
\hline
\end{tabular}

Kriteria video tidak optimal

1. Bayi sebagian besar waktunya berada pada Prechtl stadium 2 atau 4

2. Durasi gerakan secara total antara 3-5 menit

3. Banyak diselingi fase menangis

\section{Analisis Statistik}

Analisis statistik menggunakan program SPSS versi 14.0. Analisis perbedaan proporsi di antara kedua kelompok menggunakan Chi-square atau Fisher's exact, test perbedaan bermakna apabila $\mathrm{p}<0,05$.

\section{Hasil}

Di dapatkan jumlah subjek 56 bayi yang memenuhi inklusi, semua bayi mendapat izin tertulis dari orangtua untuk dilakukan perekaman video. Tiga $(5,4 \%)$ video rekaman yang tidak dapat dilakukan penilaian karena kesalahan teknik prosedur perekaman. Sejumlah 53 video bayi berhasil dianalisis dengan baik, dengan rerata usia gestasi bayi saat direkam 38,1 (SD 37,60) minggu dan rerata berat badan lahir 3084,9 (SD $642,38)$ gram. Distribusi frekuensi berdasar waktu, tempat dan parameter praktikal video rekaman disajikan pada Tabel 3.

Evaluasi praktikal dari video rekaman dengan menggunakan dua parameter yaitu video optimal dan video tidak optimal, menunjukkan hasil optimal didapatkan apabila perekaman dilakukan pada siang hari (13.00-15.00) dibandingkan bila dilakukan pada pagi hari (08.00-10.00) atau malam hari (20.00-22.00) $(p<0,05)$. Demikian pula bila dilakukan 30 menit sebelum minum akan didapatkan hasil yang lebih optimal dibandingkan 30 menit sesudah minum $(p<0,05)$. Tidak didapatkan perbedaan yang bermakna apabila perekaman dilakukan di atas mattrass khusus bila dibandingkan dengan di dalam boks bayi maupun di dalam inkubator $(p>0,05)$ (Gambar 1).

\section{Diskusi}

Penelitian tentang GMs menggunakan metode Prechtl merupakan pengalaman pertama kami di rumah sakit Dr. Soetomo Surabaya sebagai bagian awal dari studi longitudinal yang sampai saat ini sedang berlangsung. Pada makalah ini kami lebih menitikberatkan pada 
Tabel 3. Rerata usia dan berat badan lahir, serta distribusi frekuensi berdasar waktu, tempat dan parameter praktikal video rekaman dari sampel.

\begin{tabular}{|c|c|}
\hline \multicolumn{2}{|l|}{ Usia gestasi saat lahir } \\
\hline \multicolumn{2}{|l|}{ Usia gestasi saat perekaman } \\
\hline (minggu, rerata[SD]) & $38,1[37,60]$ \\
\hline \multicolumn{2}{|l|}{ Berat badan lahir } \\
\hline (gram, rerata[SD]) & $3084,9[642,38]$ \\
\hline \multicolumn{2}{|c|}{ Waktu perekaman berdasar jam, $(\mathrm{n}[\%])$} \\
\hline - Pagi hari & $9[17,0]$ \\
\hline - Siang hari & $37[69,8]$ \\
\hline - Malam hari & $7[13,2]$ \\
\hline \multicolumn{2}{|c|}{ Waktu perekaman berdasar jadwal minum, $(\mathrm{n}[\%])$} \\
\hline - 30 menit sebelum minum & $39[73,6]$ \\
\hline - 30 menit setelah minum & $14[26,4]$ \\
\hline \multicolumn{2}{|l|}{ Tempat perekaman, (n[\%]) } \\
\hline - Di atas mattrass khusus & $38[71,7]$ \\
\hline - Di dalam boks bayi & $11[20,8]$ \\
\hline - Di dalam inkubator & $4[7,5]$ \\
\hline \multicolumn{2}{|c|}{ Parameter praktikal video rekaman, $(\mathrm{n}[\%])$} \\
\hline - Video optimal & $38[71,7]$ \\
\hline - Video tidak optimal & $15[28,3]$ \\
\hline \multicolumn{2}{|l|}{ Klasifikasi kualitas GMs, (n[\%]): } \\
\hline - Normal-optimal & $1[1,9]$ \\
\hline - Normal-suboptimal & $21[39,6]$ \\
\hline - Abnormal-ringan & $24[45,3]$ \\
\hline - Abnormal-pasti & $7[13,2]$ \\
\hline
\end{tabular}

evaluasi metodologi penerapan sehingga dapat diketahui kondisi yang paling optimal untuk menerapkan metode Prechtl pada populasi bayi baru lahir di Indonesia. Analisis hasil penilaian kualitas GMs dari penelitian ini akan dipublikasikan pada makalah yang terpisah.

Studi menggunakan rekaman video untuk menilai kualitas gerakan spontan bayi baru lahir. Penilaian kualitas gerakan spontan pada bayi baru lahir sebenarnya dapat dilakukan langsung dengan mata telanjang. Namun observasi dengan mata telanjang untuk aspek kualitatif dari sebuah gerakan motorik sangat besar kemungkinannya akan menghasilkan penilaian yang subjektif dan bias. ${ }^{7,8}$ Prechtl dan peneliti lainnya dalam bidang GMs sepakat bahwa untuk dapat menilai gerakan spontan bayi dari aspek kualitas hanya dapat dilakukan secara objektif dan realistis apabila gerakan tersebut dapat didokumentasikan melalui sebuah rekaman video. ${ }^{3,7,9}$ Melalui dokumentasi video, analisis GMs dapat dilakukan oleh seorang pengamat berulang-ulang pada kesempatan yang berbeda (testretest reliability) dan dapat dicapai tingkat kesepakatan antar pengamat (inter-observer agreement) sesuai dengan yang diharapkan. Dengan demikian dapat dikatakan bahwa nilai validitas yang tinggi dari sebuah analisis GMs hanya dapat dicapai apabila menggunakan rekaman video. ${ }^{7-10}$

Analisis setiap video pada studi ini dilakukan oleh salah satu tim peneliti yang sebelumnya telah dilatih dan mendapat sertifikat metode GMs tingkat dasar. Keterbatasan tenaga pengamat yang terlatih inilah yang menjadi salah satu hambatan utama mengapa metode Prechtl belum banyak dikenal dan diterapkan di Indonesia. Menurut Hadders-Algra, 2001, prinsip dasar metode GMs dapat dipelajari melalui sebuah training khusus hanya dalam waktu dua hari. Namun untuk dapat mengaplikasikan secara praktis sehari-hari dibutuhkan pengalaman menilai paling tidak 100 video untuk dapat dikatakan sebagai pengamat yang terlatih. ${ }^{2}$ Berbagai studi membuktikan bahwa tingkat kesesuaian intra dan inter-observer metode GMs apabila dilakukan oleh tenaga yang terlatih dapat mencapai nilai kappa 0,8-1,0, sebuah bukti bahwa metode ini mempunyai reliabilitas yang hampir sempurna atau sangat baik. ${ }^{1,2,11-14}$

Penilaian kualitas GMs bayi untuk setiap rekaman video dilakukan berdasarkan analisis persepsi Gestalt dari pengamat. Melalui persepsi Gestalt, seorang pengamat dapat melakukan penilaian secara global aspek kompleksitas dan variasi serangkaian gerakan motorik. Penilaian didasarkan atas evaluasi pola gerakan yang dihasilkan oleh semua bagian tubuh bayi, terutama kepala, leher, batang tubuh dan kedua ekstremitas, sehingga penilaian tidak boleh hanya dengan mengamati pola gerakan dari satu bagian tubuh tertentu saja. ${ }^{4,7}$

Video yang berisi rekaman bayi dengan perilaku yang tergolong Prechtl 2 dan Prechtl 4 saja yang dianalisis. Alasan yang mendasari adalah perilaku bayi pada Prechtl stadium 4 merupakan kondisi bayi paling memungkinkan untuk memproduksi GMs normal, aspek kompleksitas, variasi dan fluensi dari GMs dapat dievaluasi paling optimal. Pada Precthl stadium 2, saat bayi dalam keadaan tidur aktif (fase REM) hanya aspek fluensi dari GMs yang mengalami penurunan, sedangkan kompleksitas dan variasinya tidak terganggu (Tabel 4) Dengan demikian bayi yang berada pada stadium perilaku Prechtl 2, penilaian kualitas GMs masih dapat dilakukan. ${ }^{1,15-17}$ 

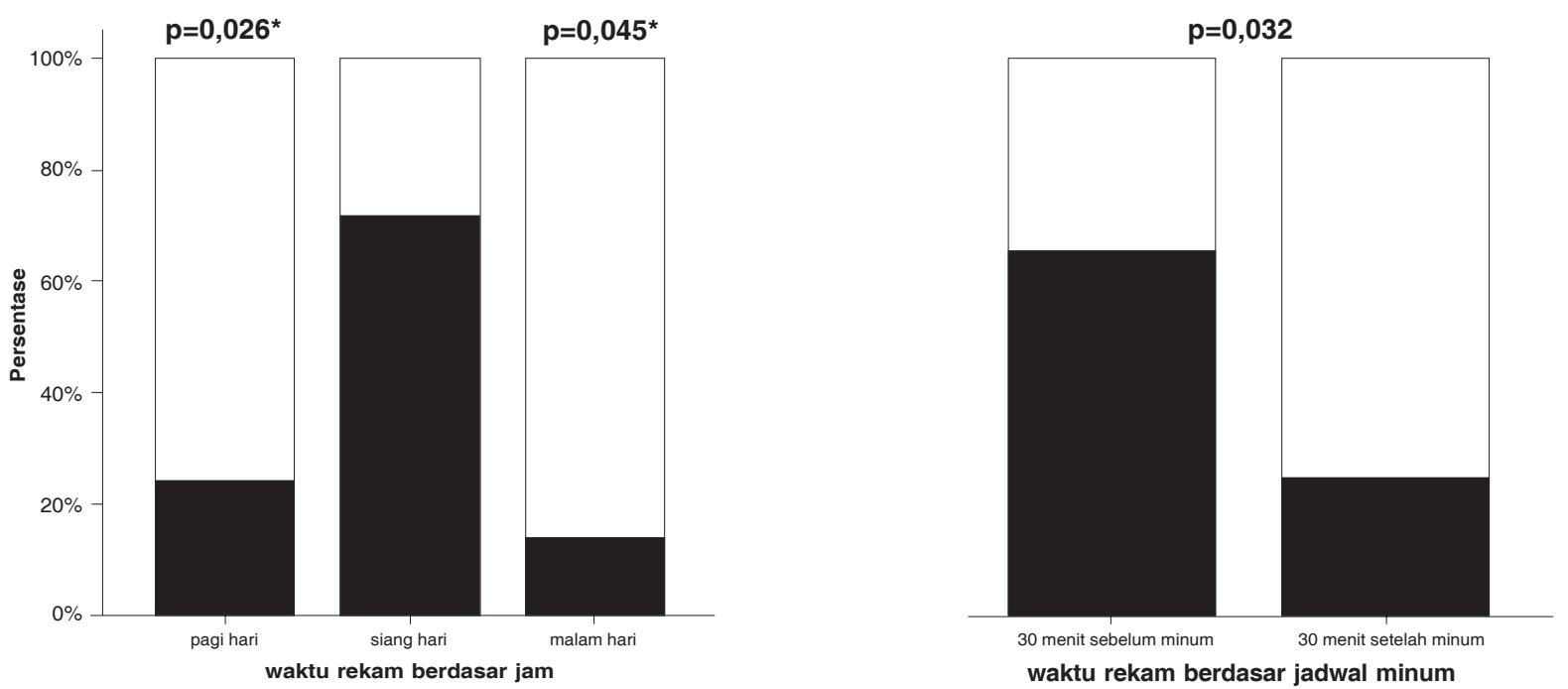

*) Dibandingkan siang hari

\#) Dibandingkan diatas mattrass khusus

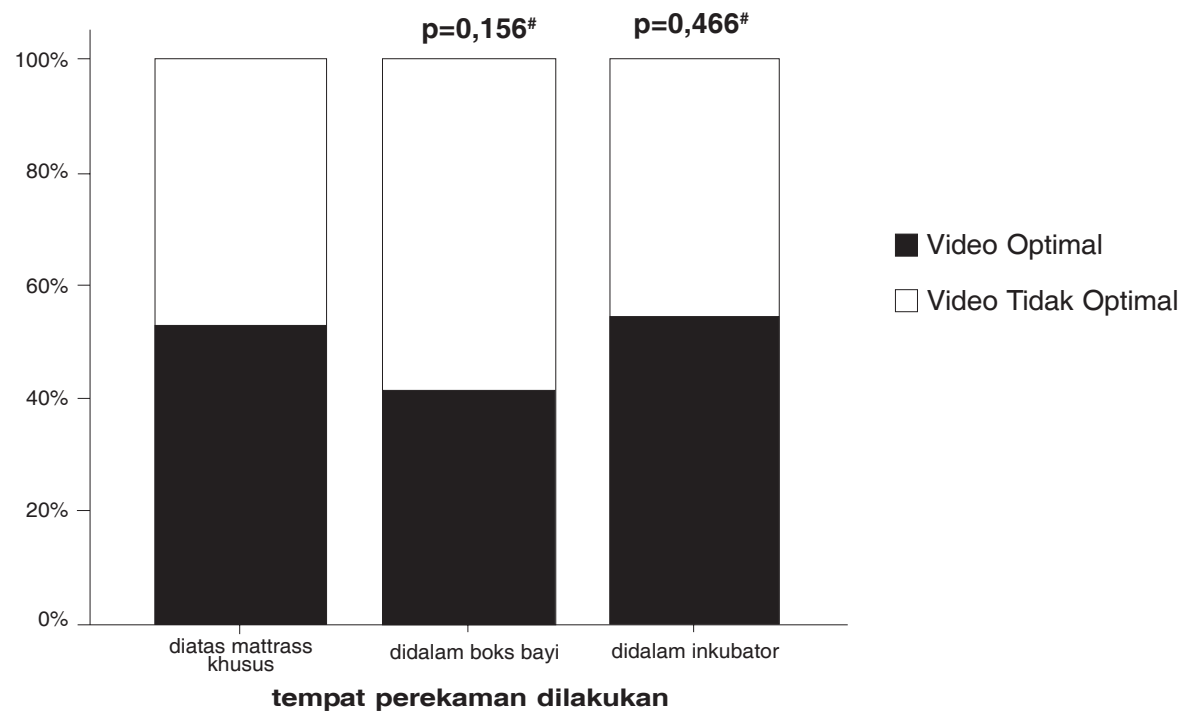

Gambar 1. Diagram batang - skala 100\% dari perbandingan kedua parameter video berdasarkan waktu dan tempat perekaman

Pada studi ini didapatkan 3 video yang tidak memenuhi syarat untuk dilakukan penilaian meskipun bayi berada dalam stadium perilaku Prechtl 4 namun dengan suasana sekitar bayi yang sangat ramai suara sehingga nampak beberapa kali mengganggu pola gerakan yang dihasilkan. Bayi harus dihindarkan dari adanya stimulasi luar yang dapat mengganggu pola gerak bayi. Sampel penelitian ini mempunyai rerata usia gestasi 38,1 minggu, Hal ini sesuai dengan pendapat sebuah studi bahwa untuk bayi yang berusia $>36-38$ minggu, penilaian kualitas GMs tidak boleh
Tabel 4. Pengaruh stadium perilaku bayi terhadap kualitas GMs. ${ }^{1}$

\begin{tabular}{|c|c|c|}
\hline $\begin{array}{c}\text { Prechtl } \\
\text { (Stadium) perilaku }\end{array}$ & $\begin{array}{c}\text { Kompleksitas } \\
\text { dan variasi }\end{array}$ & Fluensi \\
\hline 2. Tidur fase aktif atau REM & Normal & $\downarrow$ \\
\hline 4. Bangun dan aktif & Normal & Normal \\
\hline 5. Menangis & $\downarrow$ & $\downarrow$ \\
\hline Menghisap non-nutritive & $\downarrow$ & Normal \\
\hline
\end{tabular}

REM: Rapid eye movement

Stadium perilaku bayi (numerisasi menurut Prechtl) hanya muncul secara baik pada bayi di atas usia gestasi 36-38 minggu 
pada saat bayi mendapat stimulasi dari lungkungan sekitarnya. Pada usia >38 minggu, bayi mulai menampakkan stadium perilaku yang sangat dipengaruhi oleh stimulasi lingkungan. ${ }^{15}$

Bayi-bayi pada studi direkam pada saat usia satu minggu pertama (usia 2-7 hari) setelah lahir. Sesuai dengan anjuran salah satu studi sebelumnya yang berpendapat bahwa pada 2 hari pertama setelah lahir bayi masih mengalami berbagai perubahan fisiologis yang sangat fluktuatif. Perubahan ini berdampak pada instabilitas stadium perilaku bayi yang dapat mempengaruhi penilaian kualitas GMs. ${ }^{7}$ Studi lain menyimpulkan bahwa kesepakatan intra- dan interobserver penilaian GMs bayi baru lahir mencapai hasil terbaik pada kelompok usia bayi antara 3-9 hari setelah lahir. ${ }^{11}$

Durasi rekaman yang dilakukan 15-30 menit untuk setiap video. Prechtl tidak menganjurkan secara pasti mengenai durasi rekaman. Paling baik melakukannya selama 1 jam, namun untuk bayi cukup bulan durasi waktu rekaman 10 menit sudah optimal. ${ }^{7}$ Pengalaman pertama di Brasil, juga mendapatkan hasil yang cukup baik dengan melakukan perekaman dengan durasi waktu 10 menit, ${ }^{6}$ sehingga kami mengambil 15-30 menit sebagai jalan tengahnya, mengingat ini adalah pengalaman pertama kami melakukan rekaman video standar Prechtl.

Evaluasi aspek praktikal aplikasi metodee Prechtl pada studi ini kami golongkan berdasar 2 parameter yaitu video optimal dan video tidak optimal. Kriteria untuk setiap parameter kami oleh peneliti berdasarkan tingkat kesulitan untuk menganalisis setiap video rekaman. Di sebut video optimal, mutlak harus berisi rekaman gerak bayi yang berada pada stadium perilaku Prechtl 4 yaitu saat bayi dalam keadaan bangun, mata terbuka dan bergerak aktif dengan total lamanya bergerak aktif $>5$ menit. Apabila bayi hanya menampakkan gerak aktif secara total 3-5 menit, maka kami golongkan menjadi video yang tidak optimal. Studi yang dilakukan oleh Eisnpelier 1997, menyarankan penilaian GMs dapat dilakukan dengan baik apabila bayi bergerak dengan total durasi waktu $>3-5$ menit. $^{7}$ Fase menangis juga kami masukkan dalam salah satu kriteria kesulitan analisis. Pada saat bayi menangis (meskipun saat itu berada pada stadium perilaku Prechtl 2 atau 4) bayi akan mengalami gerakan yang terputus-putus, kaku dan tremulous. ${ }^{1,4}$ Sehingga apabila sebuah video berisi rekaman bayi dengan banyak fase menangis, kami golongkan menjadi video tidak optimal karena penilaian GMs menjadi lebih sulit.

Dengan menggunakan kedua parameter, penelitian membuktikan bahwa apabila rekaman video dibuat pada siang hari (13.00-15.00) dan 30 menit sebelum jadwal minum akan mendapatkan hasil video rekaman yang lebih optimal dibanding melakukan rekaman video pada waktu lainnya. Penelitian lain sebelumnya hanya mengatakan perekaman harus dibuat di antara dua jadwal minum. ${ }^{4,6}$ Belum ada penelitian mengevaluasi apakah harus dilakukan pada pagi, siang atau malam hari. Pengalaman kami menunjukkan bahwa pada 30 menit sebelum minum dan pada siang hari lebih banyak dijumpai bayi yang berada dalam keadaan bangun dan aktif untuk bergerak sedangkan pada 30 menit setelah minum, bayi sebagian besar dalam kondisi tidur, yang sangat mungkin karena dalam keadaan kenyang dan akan menunjukkan perilaku Prechtl stadium 2 sehingga kualitas GMs lebih sulit dinilai.

Tempat pengambilan rekaman yang berbeda-beda yaitu di atas mattrass khusus, di dalam boks atau di dalam inkubator, tidak mempengaruhi bayi untuk dapat menghasilkan rekaman gerak yang optimal. Hasil ini juga sesuai dengan studi sebelumnya. Aspek terpenting dari segi tempat perekaman adalah suhu yang normal dengan situasi lingkungan sekitar yang cukup tenang dan bayi berada pada tempat yang tidak menghalangi bayi untuk dapat melakukan gerakan secara spontan. ${ }^{7}$

Dari hasil penelitian ini kami menyimpulkan bahwa metode Prechtl dapat diterapkan secara optimal pada populasi bayi baru lahir di Indonesia apabila penilaian melalui rekaman video dibuat pada waktu siang hari dan 30 menit sebelum minum tanpa tergantung tempat di mana bayi direkam. Hasil penelitian ini diharapkan dapat menjadi patokan awal bagi para klinisi lainnya di Indonesia yang ingin menerapkan metode Prechtl. Masih dibutuhkan studi oleh senter-senter lain di Indonesia yang dapat dipakai sebagai pembanding, mengingat karakteristik perilaku bayi baru lahir di Indonesia tentu berbeda dengan bayi di negara Eropa atau lainnya.

\section{Daftar Pustaka}

1. Hadders-Algra M. General movements: a window for early identification of children at high risk of developmental disorders. J Pediatr 2004;145:512-8. 
2. Hadders-Algra M. Evaluation of motor function in young infants by means of the assessment of general movements: a review. Ped Phys Ther 2001;13:27-36.

3. Prechtl HFR. General movement assessment as a method of developmental neurology: new paradigms and their consequences. Dev Med Child Neurol 2001;43:836-42.

4. Hadders-Algra M, Klip-Van den Nieuwendijk AWJ, Martijn A, Van Eykern LA. Assessment of general movements: towards a better understanding of a sensitive method to evaluate brain function in young infants. Dev Med Child Neurol, 1997;39:88-98.

5. Hadders-Algra M, Groothuis AMC. Quality of general movements in infancy is related to the development of neurological dysfunction, attention deficit hyperactivity disorder and aggressive behavior. Dev Med Child Neurol 1999;41:381-91.

6. Garcia JM, Gherpelli JLD, Leone CR. The role of spontaneous general movement assessment in the neurological outcome of cerebral lesions in preterm infants. J Pediatr (Rio J) 2004;80:296-304.

7. Einspieler C, Prechtl HFR, Ferrari F. The qualitative assessment of general movements in preterm, term and young infants—review of methodology. Early Hum Dev. 1997;50:47- 60 .

8. Cioni G, Ferrari F, Prechtl HFR. Posture and spontaneous motility in fullterm infants. Early Hum Dev 1989; 18:247-62.

9. Hadders-Algra M, Nakae Y, Van Eykern LA, Klip-Van den Nieuwendijk AWJ, Prechtl HFR. The effect of be- havioral state on general movements in healthy full-term newborns: a polymyographic study. Early Hum Dev 1993;35:63-79.

10. Prechtl HFR, Fargel JW, Weinmann HM, Bakker HH. Postures, motility and respiration of low-risk preterm infants. Dev Med Child Neurol 1979;21:3-27

11. Hadders-Algra M, Prechtl HFR. Developmental course of general movements in early infancy, I: descriptive analysis of change in form. Early Hum Dev 1992;28:201-14.

12. Van Kranen-Mastenbroek V, Van Oostenbrugge R, Palmans L. Inter- and intraobserver agreement in the assessment of the quality of spontaneous movements in the newborn. Brain Dev. 1992;14:289-293.

13. Van Kranen-Mastenbroek VH, Kingma H, Caberg HB. Quality of spontaneous general movements in full-term small-for-gestational age and appropriate-for-gestational-age newborn infants. Neuropediatrics 1994; 25:145-53.

14. Kakebeeke TH, Von Siebenthal K, Largo RH. Differences in movement quality at term among preterm and term infants. Biol Neonate. 1997;71:367-378.

15. Prechtl HFR. The behavioral state of the infant-a review. Brain Res 1974;76:185-212.

16. Nijhuis JG, Prechtl HFR, Martin CB, Bots RSGM. Are there behavioral states in the human fetus?. Early Hum Dev 1982;6:177-95.

17. Prechtl HFR, Ferrari F, Cioni G. Predictive value of general movements in asphyxiated fullterm infants. Early Hum Dev. 1993;35:91-120. 